\title{
ENSINO DE HISTÓRIA E A PEDAGOGIA FREIREANA: UMA POSSIBILIDADE A PARTIR DA OBRA DO FOTÓGRAFO SEBASTIÃO SALGADO
}

DOI: $10.48075 /$ RI.V24I2.25694

Ruhama Sabião ${ }^{1}$

Audrey Barbosa ${ }^{2}$

RESUMO: Este artigo propõe-se a discutir o Ensino de História e a Pedagogia freireana, utilizando-se do trabalho do fotógrafo Sebastião Salgado. Freire acreditava que a leitura do mundo e das palavras também partiam da leitura das imagens, contestando assim uma educação bancária, que nesta perspectiva utilizaria a fotografia com fins meramente ilustrativos. Sendo assim, este trabalho buscou levantar referenciais teóricos e analisar as fotografias do fotógrafo Sebastião Salgado, como forma de articular as discussões freireanas com uma prática libertadora no Ensino de História. Percebeu-se a relevância das fotografias para a ampliação da leitura de mundo, e as possibilidades que elas carregam de desconstruir estereótipos, formar identidades e auxiliar a pensar a sociedade e as lutas sociais travadas ao longo da história.

\section{HISTORY TEACHING AND FREIRIAN PEDAGOGY: A POSSIBILITY FROM THE WORK OF PHOTOGRAPHER SEBASTIÃO SALGADO}

ABSTRACT: This article aims to discuss the Teaching of History and Freire's Pedagogy, using the work of photographer Sebastião Salgado. Freire believed that the reading of the world and words also started from the reading of images, thus contesting a banking education, which in this perspective would use photography for illustrative purposes only. Therefore, this work sought to raise theoretical references and analyze the photographs of the photographer Sebastião Salgado, as a way of articulating Freire discussions with a liberating practice in History Teaching. The relevance of the photographs was noticed for the amplification of the reading of the world, and the possibilities that they carry to deconstruct stereotypes, to form identities and to help to think the society and the social struggles waged throughout history.

Keywords: Paulo Freire; History teaching; Sebastião Salgado.

\footnotetext{
${ }^{1}$ Doutoranda em Educação e Mestre em História pela Universidade Estadual de Ponta Grossa (UEPG): E-mail ruhama.sabiao@gmail.com

${ }^{2}$ Doutoranda em Educação e Mestre em História pela Universidade Estadual de Ponta Grossa (UEPG). E-mail: audreybarbosaf@gmail.com
} 


\section{INTRODUÇÃO}

Existem muitas formas de rememorar o passado: a partir de objetos materiais, cheiros, sons, histórias, e, inclusive, pelas fotografias. Olhar para o passado significa também olhar para a História e perceber que é construída a partir de diferentes sujeitos, que inseridos no mundo deixam vestígios de suas vivências, paixões e cores que compõem suas trajetórias. Essas memórias são singulares para aqueles que se deixam afetar pelos fragmentos de história que compõem suas identidades.

Apesar disso, por muito tempo a historiografia preconizou as histórias dos grandes heróis, daqueles que realizaram feitos memoráveis, venceram guerras, alteraram regimes políticos, conquistaram grandes impérios ou mantiveram as sociedades sob seu poder, a partir da política, religião, economia ou qualquer outra forma de opressão. Às margens desses processos ficaram aqueles que foram torturados, mortos, exilados e excluídos das memórias das quais fizeram parte. Como diria Bertold Brecht (1935), em seu poema “Perguntas de um operário letrado": “Em cada página uma vitória. Quem cozinhava os festins? Em cada década um grande homem. Quem pagava as despesas? Tantas histórias, quantas perguntas...". Nesse sentido, quem foram os apagados pela memória oficial, e quanto aos derrotados nas batalhas?

Ao chamar a atenção dos leitores para a sociedade, Paulo Freire demonstra que as relações sociais são marcadas pela opressão, de determinados grupos e pessoas, variando conforme as circunstâncias. Segundo ele, somos condicionados pela sociedade em que vivemos, mas não determinados por ela, e que somente uma Educação libertadora pode conscientizar os oprimidos deste condicionamento, de forma que possam contribuir na transformação da ordem social, política e econômica. Freire (2018, p. 43) destaca que: "Quem, melhor que os oprimidos, se encontrará preparado para entender o significado terrível de uma sociedade opressora?" Entretanto, uma Pedagogia do Oprimido não é feita para os oprimidos, mas sim com eles em um processo constante de busca pela libertação.

Neste trabalho, chama-se atenção para as fotografias produzidas por Sebastião Salgado, fotógrafo brasileiro que há mais de quarenta anos registra em preto e branco as atrocidades existentes no planeta, bem como as belezas naturais. Após passar os longos anos da Ditadura Militar brasileira exilado, a partir de 1990 Salgado se dedicou a fotografar os indígenas do Brasil e da América, as condições de vida dos trabalhadores e camponeses 
em várias regiões do mundo, as regiões africanas devastadas pela seca, e outros sujeitos pertencentes a grupos sociais oprimidos.

De forma a solidarizar-se com os oprimidos e mostrar as injustiças sociais a todos os que são alcançados por suas fotografias, o trabalho de Sebastião Salgado torna-se uma possibilidade ao Ensino de História. Em uma perspectiva de humanização-desumanização dentro da história, as fotografias chocam, mas também criam sentimentos de responsabilização individual e coletiva pela humanidade, o que possibilita a restauração da humanização, colocada por Freire.

Deste modo, os tópicos seguintes tratarão da relação entre a pedagogia de Paulo Freire e o Ensino de História, bem como a possibilidade de utilização das fotografias como forma de humanização e ressignificação dos processos históricos.

\section{A PEDAGOGIA DE PAULO FREIRE E O ENSINO DE HISTÓRIA}

Ao pensar na Educação em uma sociedade opressora, o papel do ensino de História se torna ainda mais significativo, pois é a partir da conscientização da opressão vivenciada ao longo da história e da realidade vivida atualmente que os sujeitos podem começar a se libertar no mundo. Por isso, a Pedagogia de Paulo Freire, em todas as suas dimensões, está intrínseca a um Ensino de História voltado à desconstrução da história tradicional, considerada aquela que prioriza os heróis nacionais, as datas comemorativas e narrativas oficiais dos vitoriosos - seja daqueles que venceram as guerras ou daqueles que detiveram o poder de escrever a história a partir da perspectiva do seu grupo social - e a construção de novas identidades a partir da História. Para além das reflexões realizadas na obra mais conhecida de Paulo Freire, Pedagogia do Oprimido, outras ideias presentes em Pedagogia da Esperança, por exemplo, possuem abordagens que conversam com as propostas do Ensino de História em uma perspectiva libertadora.

Com o advento da Escola dos Annales ${ }^{3}$, e uma nova perspectiva historiográfica para além dos documentos oficiais, novos sujeitos passaram a compor a historiografia, porém, ainda como coadjuvantes de processos dos quais protagonizaram em muitos aspectos. No

\footnotetext{
${ }^{3}$ Movimento francês que iniciou a partir do periódico acadêmico Annales d'histoire économique et sociale, fundada por Lucien Febvre e Marc Bloch, que tinham como principal crítica a história positivista, que priorizada por um método único de pesquisa histórica, a partir de documentos oficiais e que privilegiava os fatos políticos e econômicos em detrimento dos sociais e culturais. Esses autores ficaram conhecidos como a Primeira Geração (1929-1949), seguidos por Fernand Braudel, como a Segunda Geração (1946-1968) e Jacques Le Goff e Pierre Nora, como a Terceira Geração (1968-1989).
} 
Brasil, o primeiro movimento por um Ensino de História voltado aos sujeitos até então marginalizados dos processos históricos foi a obra "Coleção História Nova", organizada por alguns autores vinculados ao ISEB ${ }^{4}$ (Instituto Superior de Estudos Brasileiros), como Nelson Werneck Sodré, no período que antecedeu a ditadura militar. Em um contexto ditatorial, a obra ameaçava a hegemonia de sujeitos históricos que exaltavam os valores da pátria e eram considerados heróis e, por isso, sua circulação foi proibida. Somente com o fim do regime militar as discussões acerca de um ensino de História mais crítico voltaram a tomar fôlego nas políticas educacionais.

Mesmo iniciando ainda no século XX, o processo de desconstrução de narrativas históricas tradicionais é contínuo. No ano de 2019, a escola de samba vencedora do Carnaval no Rio de Janeiro, a Mangueira, apresentou um samba-enredo intitulado Histórias para ninar gente grande, em que a narrativa trazia os sujeitos históricos marginalizados, além de nomes de heróis que, muitas vezes, não se encontram nos livros didáticos, como no trecho: "Brasil chegou a vez, de ouvir as Marias, Mahins, Marielles, Malês [...]" (MANGUEIRA, 2019), fazendo referência a sujeitos históricos que protagonizaram movimentos como a luta abolicionista e outros movimentos sociais.

Além desse, outros trechos deixaram claro que o samba trazia a "história que a história não conta", o que levantou muitos olhares da sociedade para algo que já vem sendo debatido pela comunidade científica dos historiadores há anos (BURKE, 1992; HOBSBAWM; RANGER, 1997; PERROT, 2017). Isso demonstra que, apesar dos esforços empreendidos pelos debates acadêmicos, eles nem sempre alcançam a sociedade da mesma forma.

Algo a ser considerado ao se utilizar de Paulo Freire para pensar o ensino de História é que o autor é um sujeito do seu tempo. Ele viveu o período da ditadura militar já na sua maturidade, e por isso, sofreu a duras penas o exílio, em que descreve a saudade que sente do seu país e a vontade de poder fazer mais pelo Brasil (FREIRE, 2001a). Em um contexto de autoritarismo, em que a América Latina foi palco de ditaduras militares, Paulo Freire representa a resistência, não somente como intelectual transformador do espaço em que vive, mas também como juventude, já que assim enxerga a si mesmo durante toda a vida.

\footnotetext{
${ }^{4}$ O instituto foi criado em 1955, ainda no governo de Café Filho, mas é no governo de Juscelino Kubitschek que ganha maior força e é destinado a uma sede própria no Rio de Janeiro. O grupo contava com intelectuais com perspectivas diferentes, e que tinham determinada influência nos ideais de desenvolvimento do Brasil, pensando também em uma direção cultural e social. Até 1964, houveram diferentes fases do instituto, sendo de 1961 a 1964 mais voltada à atuação de esquerda e à uma aproximação com os movimentos sociais do período (LOURENÇO, 2008).
} 
Por isso, Paulo Freire escreve sobre Educação, mas em um período histórico específico, em que o pensamento progressista e revolucionário enfrentava intensa oposição.

Ensinar História, principalmente no ambiente escolar, vai ao encontro da dialogicidade abordada por Paulo Freire, quando salientou que o diálogo começa já na escolha do conteúdo programático (FREIRE, 2018b). Sabe-se que não é possível ensinar toda a história da humanidade, em todos os tempos e locais, de todas as formas possíveis e a partir de todos os olhares, por isso, é preciso selecionar. A seleção dos conteúdos, para Moreno (2004), além de estar baseada nos avanços da ciência histórica, deve levar ao autoconhecimento, que permita ao educando entender a si mesmo e à sociedade de maneira mais ampla. Essa ideia coaduna com a concepção problematizadora da Educação, em contraponto à concepção bancária, em que o educando é mero receptor de conteúdos prontos. Freire entendia que os seres humanos, como seres históricos, são inconclusos e conscientes de sua inconclusão, e que uma Educação libertadora procura formar seres éticos, que decidem, optam e agem a favor de ou contra algo/alguém. Nesse sentido, salientou que:

Entre nós, mulheres e homens, a inconclusão se sabe como tal. Mais ainda, a inconclusão que se reconhece a si mesma implica necessariamente a inserção do sujeito inacabado num permanente processo social de busca. Historio-sócio-culturais, mulheres e homens nos tornamos seres em que curiosidade, ultrapassando os limites que the são peculiares no domínio vital, se torna fundamente da produção do conhecimento. Mais ainda, a curiosidade é já conhecimento. Como a linguagem que anima a curiosidade e com ela se anima, é também conhecimento e não só expressão dele (FREIRE, 1997, p. 55).

Nessa perspectiva, o ensino de História deve buscar "desenvolver uma racionalidade que permita descrever, explicar e dar sentido" (ROSA, 2007, p. 53) ao conhecimento histórico trabalhado em sala de aula, proporcionando isto aos educandos. Dar sentido aos conteúdos vai muito além da mera recepção por parte deles, mediatizada pelo educador, mas faz parte de uma educação autêntica, que "[...] não se faz de $A$ para $B$ ou de $A$ sobre $B$, mas de A com B, mediatizados pelo mundo" (FREIRE, 2018, p. 116b).

É a partir dessa mediatização do objeto de conhecimento entre as partes que o diálogo permite entender "[...] visões impregnadas de anseios, de dúvidas, de esperanças ou desesperanças que implicitam temas significativos, à base dos quais se constituirá o conteúdo programático da educação" (FREIRE, 2018, p. 116b). Por isso, o conteúdo já é o diálogo constante com o educando, que deixa de ter uma postura de mero receptor e passa 
a ser sujeito do próprio conhecimento, isso dependendo de como o educador, como intelectual transformador, abordará as aulas.

Na disciplina de História, o diálogo faz ainda mais sentido, pois, de acordo com Freire (2018, p. 133b) “Falar, por exemplo, em democracia e silenciar o povo é uma farsa. Falar em humanismo e negar os homens é uma mentira". Não somente o conceito de democracia, mas todos os outros que envolvem a participação do povo e o protagonismo dos oprimidos mediante uma sociedade opressora é uma farsa se não envolver, de fato, a participação popular, e no caso da Educação, o envolvimento dos educandos.

Os educandos devem compreender que a História não é somente o que já foi, mas pode também ser o que virá e que o presente, em sentido literal, é uma dádiva para aqueles que entendem que não há determinismo na História, pois se assim fosse "não haveria espaço para opção, ruptura" (FREIRE, 2001a, p. 39). Freire ressalta constantemente que ensinar "[...] não é a pura transferência mecânica do perfil do conteúdo que o professor faz ao aluno, passivo e dócil" (FREIRE, 2018, p. 98a), ao contrário, é um diálogo constante a partir da leitura de mundo que os educandos carregam consigo, e que torna-se ponto de partida para trabalhar também outros saberes. Dessa forma, o ensino deve ser um ato criador, crítico, e não mecânico, pois "A curiosidade do professor e dos alunos, em ação, se encontra na base do ensinar-aprender" (FREIRE, 2018a, p. 113).

O Ensino de História pautado na perspectiva freireana, além de necessitar da seleção de conteúdo, ou seja, de não buscar uma história total dos acontecimentos, mas algo que faça sentido aos educandos, também precisa ensinar para a liberdade, e para a conscientização da opressão. Desse modo, o educador deve buscar atuar de forma que não haja a ameaça de uma atração pelos opressores por parte dos educandos, já que os opressores, em sua maioria, realizaram feitos que deixaram marcas na história oficial e atraem o olhar de muitos.

Para a construção do pensamento crítico, entende-se ser necessário uma educação para a pergunta e não somente para a resposta (FREIRE, 2001), é preciso que os conteúdos despertem a curiosidade, agucem os sentidos e permitam a construção de novos conhecimentos, e não somente uma memorização mecânica, visando um bom desempenho nas avaliações. Um ensino de História que não forma para a criticidade e para posicionar-se diante do mundo de forma humanizada e com empatia, sempre será visto como "matéria decorativa". 
Espera-se que em seu percurso formativo, o educador possa tomar uma posição diante do ensino, entender o contexto em que os educandos estão inseridos, suas necessidades, e como a história pode ser ensinada a partir de um ato de esperança e fé, estes que movem a concretização de sonhos e o vislumbrar de um mundo melhor para todos aqueles que são oprimidos. De acordo com Freire (2018, p. 126a), "Sonhar não é apenas um ato político necessário, mas também uma conotação da forma histórico-social de estar sendo de mulheres e homens [...] que, dentro da história, se acha em permanente processo de tornar-se".

Por isso, ensinar História requer ir além do texto, da memória, da oralidade, mas também trabalhar com o visual, tão estimado em uma sociedade globalizada. Neste sentido, as fotografias tornam-se importantes na luta pela conscientização da sociedade opressora e na busca constante de estar sendo, de forma significativa no mundo. Segundo Bittencourt (2005, p. 366) "rever fotos significa relembrar, rememorar ou mesmo "ver" um passado desconhecido", que neste caso não se aplica somente como passado, mas também um presente muitas vezes desconhecido e que é fruto de processos históricos dos quais é necessário conhecer, para agir em prol da transformação.

\section{“LEITURA DO MUNDO, LEITURA DAS IMAGENS": PAULO FREIRE E O USO DO VISUAL}

Em suas manifestações escritas e orais, Freire sempre enfatizou que a leitura do mundo precede a leitura da palavra. Segundo o educador, as vivências, o cotidiano, as crenças e os olhares de quem aprende se apresentam antes do ato de aprender e, por essa razão, são ativas nesse processo. Nessa perspectiva, o aprender está intimamente ligado ao mundo que cerca quem aprende, tornando a "aprendizagem da palavra" uma das etapas do processo, não o fim dele.

Freire ressaltou que a base de sua metodologia de alfabetização residia na centralidade que o diálogo ocupava nesse processo de leitura do mundo. O método proposto por ele foi construído na relação entre três aspectos, a saber: a) no método ativo, diagonal, crítico e criticizador; b) na modificação do conteúdo programático da educação; c) e no uso de técnicas como a da redução e da codificação (FREIRE, 1967). 
De forma sucinta, indica-se seu método pelas seguintes fases: primeiro, levantamento do universo vocabular; segundo, escolha das palavras do universo vocabular; terceiro, criação de situações existências típicas; e, por último, fichas roteiros para o debate.

Um exemplo acerca do uso de fotografias, citado por Paulo Freire (1967), ocorreu com a palavra geradora "favela". No processo educativo a imagem de uma favela era apresentada, promovendo-se o diálogo sobre seu significado e as necessidades fundamentais de todas as pessoas como: "habitação, alimentação, vestuário, saúde, educação". Em seguida apresentava-se "um slide apenas com a palavra: FAVELA". A exploração da palavra fazia-se pela separação em sílabas e famílias fonêmicas (FREIRE, 1967, p. 144).

O uso de imagens por Freire no processo de alfabetização vem sendo analisado em diversos estudos, dentre os quais destacam-se: o artigo Freire e o uso pedagógico da imagem visual (2017), de autoria de Raquel Alcantara e Erenildo Carlos, e a monografia $A$ Arte/Educação na perspectiva da Educação Popular de Paulo Freire (2008), produzida por Jaqueline dos Santos Trevisan, apresentando o projeto "Nós, Sebastião e a Comunidade".

No primeiro caso, Alcantara e Carlos (2017), ao analisarem os usos que Paulo Freire fez da imagem no seu trabalho educativo, ressaltam que a pedagogia freireana conferiu à imagem um "grau significativo de relevância [...] usando-a como mediação da aprendizagem da inteligibilidade do mundo" (ALCANTARA; CARLOS, 2017, p. 57). São perceptíveis três noções de imagem na perspectiva freireana: representação de mundo, código visual e objeto do conhecimento - e três possibilidades de uso - associação mnemônica, ilustrativa e de mediação do conhecimento (ALCANTARA; CARLOS, 2017).

No que se refere à noção da imagem como representação de mundo, os autores enfatizam que a imagem na obra freireana se refere a algo que existe, ou seja, na relação entre a imagem e seu referente (ALCANTARA; CARLOS, 2017). Quanto ao código visual, segundo os autores, este diz respeito a imagem como um código lido pelos educandos, isto é, "há um deslocamento da representação centrada na referência, para a relação entre o significante (as marcas empírico-visuais) e o significado (as ideias relacionadas ao significante)" (ALCANTARA; CARLOS, 2017, p. 58). Por fim, quanto a imagem como objeto do conhecimento, este compreende que a própria imagem é objeto de experiências e especulações educativas, e, por isso, "possibilita a formulação de questões problema e o 
estabelecimento de hipóteses a respeito da própria imagem, e não, do que ela representa ou intermedeia" (ALCANTARA; CARLOS, 2017, p. 59).

Quanto às possibilidades de uso da imagem na perspectiva da pedagogia freireana, os autores enfatizam que esta pode ocorrer de três maneiras: primeiro, por meio da associação mnemônica que "aciona elementos como memória, associação e conteúdo" (ALCANTARA; CARLOS, 2017, p. 59); segundo, de forma ilustrativa para situações ou noções que serão problematizadas no processo educativo; e terceiro, como mediação do conhecimento, isto é, quando a imagem é utilizada como estratégia de problematização de conhecimentos, tornando-se "uma forma de se distanciar da situação codificada para questioná-la. Logo, com essa possibilidade de uso, a situação existencial assume o caráter de situação-problema" (ALCANTARA; CARLOS, 2017, p. 59).

O trabalho de Trevisan (2008), apresenta o projeto "Nós, Sebastião e a Comunidade". Desenvolvido com estudantes de diferentes faixas etárias, variando entre os 15 e 50 anos, o projeto buscou abordar o ensino de arte a partir da vivência dos educandos, para que pudessem atribuir significado ao seu aprendizado, e para isso, recorria à articulação com as fotografias de Sebastião Salgado (TREVISAN, 2008).

Uma das premissas do projeto era voltar-se às imagens que remetiam à vivência dos educandos. Para isso, fizeram uso, sobretudo, das fotografias presentes na obra "Trabalhadores". Nesse projeto a fotografia de Sebastião Salgado provocou a mediação para o diálogo, possibilitando aos educandos análises críticas de seu contexto por meio do click. Afinal, Paulo Freire propôs o decifrar juntamente com o decodificar, significar, ressignificar, apropriar - práticas estas fundamentais para uma educação fundada na liberdade (TREVISAN, 2008).

Por fim, nesse projeto didático foi possível aos educandos estabelecer relações da sua realidade com a obra de Sebastião Salgado e dessa forma construir o conhecimento histórico e contextualizado do individual, do local e do global. Segundo a pesquisadora: "a percepção e sensibilidade destes educandos foram aguçadas a partir do entendimento da fotografia e sua decodificação" (TREVISAN, 2008, p. 127).

O que se propõe com a presente reflexão é ampliar a dinâmica "leitura do mundo, leitura da palavra", para a "leitura do mundo, leitura - também - das imagens". Portanto, adota-se a perspectiva de educação crítica sempre defendida por Freire, reiterando e refutando a simples educação bancária e o uso meramente ilustrativo das imagens. Nesse 
ínterim, o visual é uma fonte rica para a problematização histórica, mas também artística, social, tecnológica, cultural, ética e estética.

\section{PEDAGOGIA FREIREANA E FOTOGRAFIAS: UMA ANÁLISE DE SEBASTIÃO SALGADO}

Frente às reflexões expostas anteriormente, neste momento propõe-se uma análise das fotografias de Sebastião Salgado, tendo sob perspectiva as leituras realizadas acerca da metodologia de Paulo Freire e os objetivos do ensino de História.

Cabe destacar que o intuito não foi propor uma receita regrada e fechada de análise das obras de Sebastião Salgado, o que fugiria até mesmo do referencial freiriano se isso fosse sugerido por meio das análises. O objetivo foi pensar uma perspectiva de análise que sirva como ponto de partida para as aulas de História que abordam criticamente diferentes temas, como fluxos migratórios, crise humanitária, direitos humanos, e que pode - e deve ser reavaliada e readequada a cada contexto.

Para isso, recorreu-se a alguns dos retratos produzidos por Sebastião Salgado, que compõem a obra Êxodos: processos migratórios (1999), e que foram disponibilizados pelo projeto Exodos programa educacional ${ }^{5}$, por meio do livro A Narrativa do olhar (2000), escrito por Tereza Aline Pereira de Queiroz.

As fotografias tratam de problemáticas e tensões do presente, sobretudo, no que diz respeito aos fluxos migratórios, à violência urbana e à desigualdade social. Além disso, é necessário ressaltar que Sebastião Salgado deve ser reconhecido como um agente cultural (KOSSOY, 2014), logo, sua produção temporal e cultural remete para uma narrativa particular, e que, provavelmente, pode ser diferente de outras.

Partindo de tais considerações, interessa analisar a importância da "visualização da imagem, não na sua memorização, estabelecendo o vínculo semântico com o objeto por meio de sua representação em slide ou fotograma" (FREIRE, 1967, p. 115).

\footnotetext{
${ }^{5}$ O projeto em questão foi fruto de uma parceria entre Sebastião Salgado, o Diversitas (Núcleo de Estudos das Diversidades, Intolerâncias e Conflitos) da Universidade de São Paulo (USP), o Departamento de História (USP) e o SESC/SP, cujo objetivo foi organizar um material didático e oficinas de trabalho para professores das escolas públicas e assentamentos rurais do Movimento Sem Terra. Dessa iniciativa, desenvolvida no ano de 2000, foram produzidos três livros, sendo eles: A Narrativa do Olhar, Fotojornalismo e Deslocamentos Populacionais e Novas Solidariedades, materiais que hoje são disponibilizados para acesso livre. Para mais informações, acesse o site: http://diversitas.fflch.usp.br/exodos-programa-educacional.
} 
Nesse sentido, a Fotografia 1, foi tirada em Melila, cidade espanhola autônoma que fica localizada no território do Marrocos, em 1997. Nela, há um jovem negro que parecer viver em um carro - haja visto seus pertences no mesmo. Quando se observa esse retrato algumas palavras vêm à mente, como: submoradia, abandono, adaptação, descaso etc. Enfim, termos que na nossa leitura compõem o universo vocabular da imagem. Esta fase num primeiro momento pode parecer meramente especulativa, mas ressalta-se sua importância para o levantamento de hipóteses e construção de um conhecimento.

FOTOGRAFIA 1 - Campo da Granja Agrícola perto do aeroporto de Melila, Marrocos (1997).

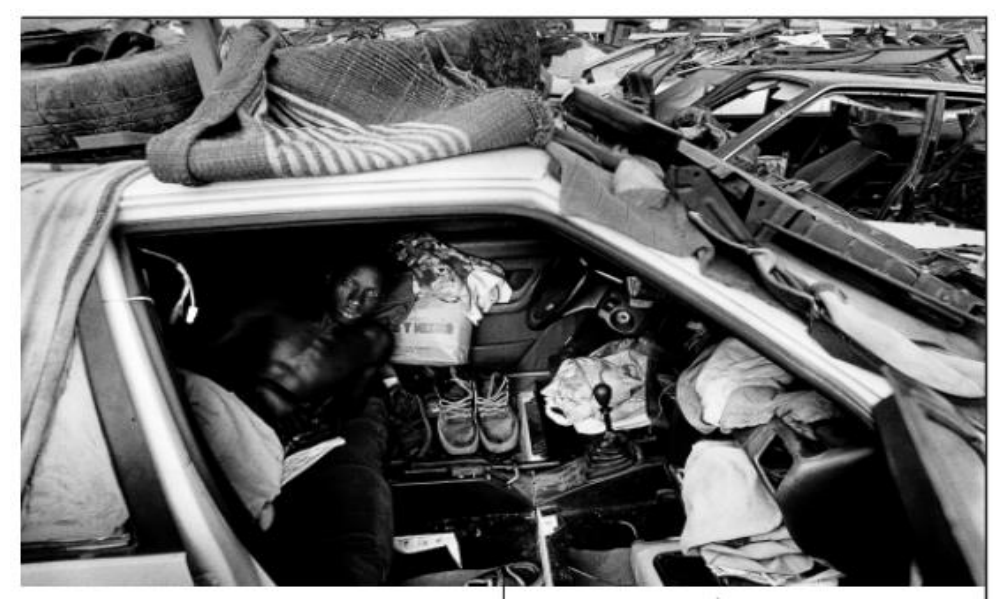

Autoria: Sebastião Salgado (1997).

As questões que se colocam a este retrato, que sensibiliza para o descaso e a falta de condições dignas, são: Quem é este jovem negro? Onde ele está? Para responder estas indagações, volta-se para a análise dos elementos escritos da obra, como a legenda, e a ação de pesquisa.

O local indicado na foto, o campo de Granja Agrícola, localizada na cidade de Melila no Marrocos, pode ser compreendido como a linha divisória entre dois lugares: ao sul, toda a complexidade do continente africano; ao norte, o Mar de Alborão, e a entrada ao continente europeu via território espanhol.

Em reportagem do ano de 1997, contemporânea a produção do retrato (Fotografia 1), a redação do jornal Folha de S. Paulo destacou que a posição geográfica de Melila a colocava como um importante "filtro entre a miséria africana e a prosperidade europeia" (FOLHA DE SÃO PAULO, 1997). Por esta razão, a cidade era repleta de pequenos guetos que serviam como local de moradia de mulheres e homens refugiados de diferentes países do continente africano, e que ali chegavam com o objetivo de conseguir migrar para a Europa. A 
reportagem destaca ainda que estes guetos ofereciam condições precárias de vida, sendo que os "privilegiados conseguem lugar nos galpões que servem como abrigo, enquanto o resto vive em barracos ou dentro de carros convertidos em casas" (FOLHA DE S. PAULO, 1997). Situação essa que leva novamente ao jovem do retrato analisado e que contribui na reflexão sobre a questão: Quem é ele? Onde ele está? Como sua existência pode ser significada?

As discussões não se esgotam neste artigo, mas a fotografia suscita problemáticas e hipóteses que levam a reflexão acerca de pessoas e lugares. Nesse caso, este jovem pode ser compreendido como um dos tantos refugiados que por motivos diversos migram de sua terra natal rumo a outros lugares em busca de melhores condições. Contudo, tal caminho não foi - e não é - fácil. Assim como em 1997, atualmente os refugiados sofrem o descaso governamental, com o preconceito social, com a falta de oportunidades e assistência, privados de seus direitos fundamentais.

Quanto a Fotografia 2, produzida por Sebastião Salgado no campo de Nahr el-Bared, região de Trípoli, norte do Líbano, em 1998, também nos remete a condição de vida de refugiados, mas dessa vez por uma perspectiva distinta. Diferente dos guetos de Melila, o campo Nahr el-Bared não se tratava de um espaço de fluxo de um lugar para o outro, mas sim um espaço de moradia de famílias, algumas das quais viveram por décadas no local, até a primeira desativação do campo em 2007.

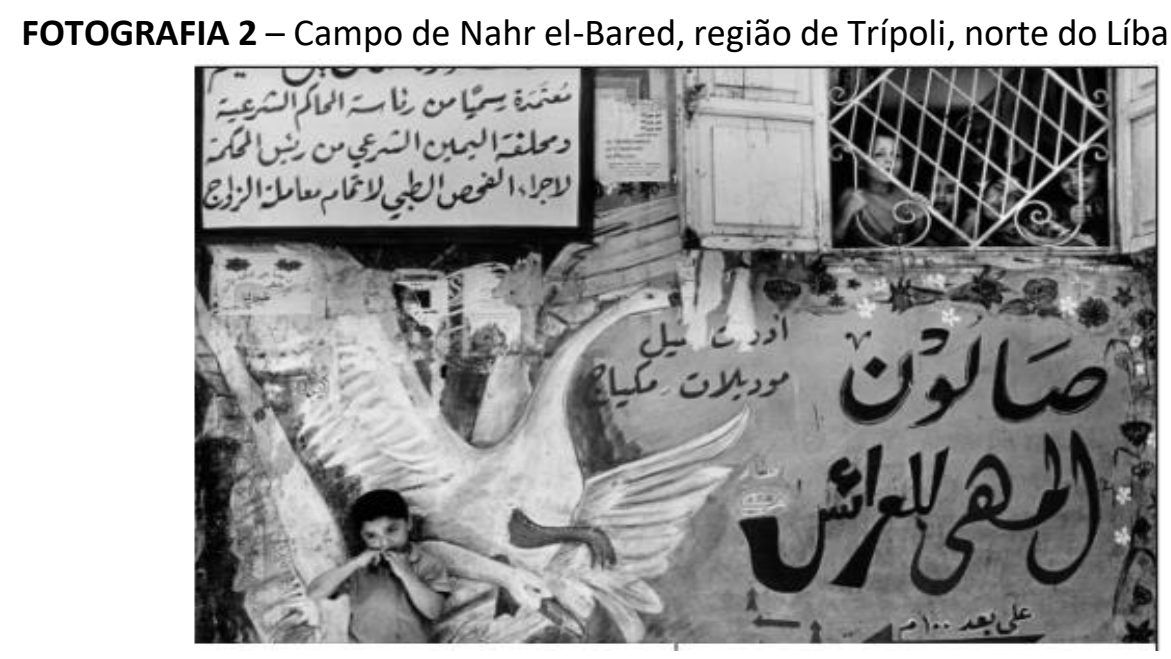

Autoria: Sebastião Salgado (1998).

O primeiro momento de análise, como pontuado anteriormente, consiste em estabelecer o universo vocabular que esta fotografia remete, como a escrita árabe, a 
religiosidade árabe-muçulmana e a infância. Cabe destacar que é necessário compreender que as pessoas apresentam diferentes olhares para a fotografia, afinal, são diferentes sujeitos, e o potencial da fotografia não é limitar um registro do mundo, mas instigar várias leituras e compreensões.

A imagem remete à questão de que as guerras não envolvem apenas soldados e governos, vai além do campo político e militar, afeta a vida de pessoas e o desenvolvimento de crianças que passam por traumas que as acompanham a vida toda.

Um exemplo é o próprio campo de Nahr el-Bared. Quando ocorreu sua desativação, no ano de 2007, centenas de crianças que tinham no campo sua "moradia" tiveram de ser encaminhadas para outros lugares, algumas órfãs. Segundo reportagem do jornalista Tariq Saleh para o jornal a Folha de S. Paulo (2007), muitas dessas crianças desenvolveram traumas profundos do conflito, como ansiedade, desânimo, medo de barulho e de escuro, falta de apetite, fome excessiva e a lembrança dos mortos (FOLHA DE S. PAULO, 2007).

Refletir acerca dos conflitos e dos campos de refugiados pela perspectiva da vivência de crianças e cruzar seus relatos - como ocorreu no projeto "Promessas de um novo mundo" $(2000)^{6}$ - sensibiliza a ouvir e observar os sujeitos que mais sofrem em meio a guerras, torna o olhar mais atento a como essas crianças vivem no presente, lembrando que são elas quem farão o futuro.

Dessa forma, é preciso refletir acerca dessas palavras do universo vocabular, trabalhando-as como conceitos para construir um raciocínio lógico sobre a fotografia, por meio de questões como: $O$ que se conhece sobre a região? Sobre o lugar fotografado, ou até mesmo, sobre o próprio fotógrafo? Esses questionamentos propiciam uma narrativa específica acerca da fotografia, que por meio da decodificação da imagem possibilita, também, decodificar as relações sociais presentes num dado país e momento, como a migração entre continentes, as condições de moradia e as pessoas em situação de rua.

\section{CONSIDERAÇÕES FINAIS}

Paulo Freire propõe a dialogicidade entre educador e educandos no processo ensinoaprendizagem, que mediatizados pelo mundo em busca de uma conscientização da

\footnotetext{
${ }^{6}$ Promises (título em inglês) é um documentário produzidos em 2000, pelos diretores B.Z. Goldberg, Justine Shapiro e Carlos Bolado que coleta relato de sete crianças que convivem direta ou diretamente com os conflitos na Palestina e que possuem diferentes origens sociais, desde a classe média israelense até moradores de campos da Cisjordânia, alguns judeus, outros árabes-muçulmanos (LIMA, 2004).
}

Ideação. Revista do Centro de Educação, Letras e Saúde. v. 23, n², 2021. e-ISSN: 1982-3010. 
opressão, por meio da Educação libertadora. O ensino de História, em uma perspectiva de desconstrução das narrativas oficiais, vai de encontro às concepções de Paulo Freire, e torna-se um espaço em que é possível criar um sentimento de pertencimento ao grupo social em que está inserido, e assim, se conscientizar das opressões, partindo desta consciência para obter mecanismos que possibilitem a própria libertação e uma mudança do mundo.

Diante de uma perspectiva crítica e dialógica de Educação, as discussões de Paulo Freire, articuladas com o ensino de História, têm como possibilidade a utilização de produções fotográficas, de forma a realizar a leitura do mundo por meio da leitura das imagens. Em uma sociedade extremamente visual, destaca-se a urgência em olhar para as fotografias de forma a suscitar sentimentos que possibilitem a transformação da sociedade, talvez um estranhamento, pertencimento, esperança, comoção, e infinitos sentimentos que as fotografias carregam consigo e que podem ser lidos. Esta leitura pode ser realizada da forma como Freire propõe, em constante diálogo e repensar do mundo, assim como as fotografias trazidas neste trabalho, que suscitaram temas como: como migração, disputas territoriais, diversidade étnica, religiosidades etc.

O fotógrafo Sebastião Salgado denuncia as formas de opressão existentes na sociedade, em diferentes níveis e aspectos, de forma que estas imagens não são meras representações, mas instrumentos reais e possíveis de transformação.

Entende-se que a importância dessas reflexões está na possibilidade de articulação da pedagogia freireana com o Ensino de História em um mundo visual. Em processo de constante desenvolvimento cognitivo, socioemocional, entre outros aspectos, os educandos têm o visual presente em todos os aspectos de suas vidas, e por isso, as fotografias consistem em: educar o olhar para as imagens que estão à volta deles e fazer dos sentimentos que elas geram uma possibilidade de transformação do mundo, como a proposta de Educação de Paulo Freire sugere.

\section{REFERÊNCIAS}

ALCANTARA, R. R. V.; CARLOS, E. J. Freire e o uso pedagógico da imagem visual. Revista Reflexão e Ação, Santa Cruz, v.25, n. 2, p. 46-64, 2017. DOI: https://doi.org/10.17058/rea.v25i2.8975 
BITTENCOURT, C. Documentos não escritos em sala de aula. In: BITTENCOURT, Circe. Ensino de História: fundamentos e métodos. São Paulo: Cortez Editora, 2005. p. 353-407.

BRECHT, B. Perguntas de um operário iletrado, 1935.

BURKE, P. A escrita da História: novas perspectivas. Trad. de Magda Lopes. São Paulo: Editora UNESP, 1992.

CARVALHO, V. V. M. As imagens no "Método de Paulo Freire", na experiência de Angicos (RN) - 1963. Revista de Educação em Questão, Natal, v. 21, n.7, p. 98-115, 2004.

FOLHA DE S. PAULO. Entre dois mundos: Espanha confina imigrantes da África. Folha de São Paulo, 25 de outubro de 1997. Disponível em: <https://www1.folha.uol.com.br/fsp/mundo/ft251003.htm>. Acesso em: 19 jun. 20.

FOLHA DE S. PAULO. No Líbano, instituto trata os traumas de crianças palestina. Folha de São Paulo, 24 de junho de 2007. Disponível em: <https://www1.folha.uol.com.br/fsp/mundo/ft2406200712.htm>. Acesso em 20 jun. 20.

FREIRE, P. Educação e conscientização. In: FREIRE, Paulo. Educação como prática de liberdade. Editora Paz e Terra: Rio de Janeiro, 1967, p. 101-123.

FREIRE, P. Pedagogia da Autonomia: saberes necessários à prática educativa. Paz e Terra: São Paulo, 1997.

FREIRE, P. À sombra desta mangueira. 6 ed. São Paulo: Olho d'Água, 2001a.

FREIRE, P. Pedagogia da Esperança. 24 ed. Rio de Janeiro/São Paulo: Paz e Terra, 2018a.

FREIRE, P. Pedagogia do Oprimido. 66 ed. Rio de Janeiro/São Paulo: Paz e Terra, 2018b.

HOBSBAWM, E.; RANGER, T. A invenção das tradições. Rio de Janeiro: Paz e Terra, 1997.

KOSSOY, B. Os tempos da fotografia. 3 ed. São Paulo: Ateliê Editorial, 2014.

LIMA, M. I. A. O cinema e a Visão da Criança em conflitos políticos. Projeto Experimental (Habilitação em Jornalismo). Escola de Comunicação, Universidade Federal do Rio de Janeiro, Rio de Janeiro, 2004. Disponível em: <https://pantheon.ufrj.br/bitstream/11422/800/3/MLima.pdf>. Acesso em: 20 jun. 20.

LOURENÇO, E. História nova no Brasil: revisitando uma obra polêmica. Revista Brasileira de História. São Paulo, v. 28, n. 56, p. 385-406, 2008.

MANGUEIRA. Histórias para ninar gente grande. Estação Primeira de Mangueira, 2018.

MORENO, J. C. Pensar a História. Pensar seu Ensino. Curitiba: Faculdades Bagozzi, mimeo, 2004. 
PERROT, M. Os excluídos da história: operários, mulheres e prisioneiros. Rio de Janeiro: Paz e Terra, 2017.

QUEIROZ, T. A.P. A narrativa do olhar. In: Êxodos programa educacional, leituras narrativas e novas solidariedades no mundo contemporâneo. V.03. São Paulo: SESC, 2000.

http://joinville.ifsc.edu.br/ mauricio.camara/Quarto\%20m\%C3\%B3dulo/Sebasti\%C3\%A30\% 20Salgado\%20\%C3\%8Axodos\%202.pdf Acesso em: 25 abr. 2020.

ROSA, A. Recordar, descrever e explicar o passado. O que, como e para o futuro de quem? CARRETERO, M.; ROSA, A.; GONZÁLEZ, M. F. (orgs.). Ensino da História e Memória Coletiva. Porto Alegre: Artmed, 2007. p. 53-60.

TREVISAN, J. S. A Arte/Educação na perspectiva da Educação Popular de Paulo Freire. $131 \mathrm{f}$. Dissertação (Mestrado em Educação). Universidade Regional do Noroeste do Estado do Rio Grande do Sul, ljuí, 2008.

Recebido em 27 de agosto de 2020.

Aprovado em 08 de janeiro de 2021.

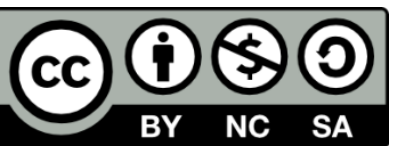

